\title{
The Impact of Media Coverage on Ethnic Conflict between Japanese and Koreans in Japan
}

\author{
Jeonghun Min
}

\begin{abstract}
This study examines how the issues aggravating tensions in North KoreaJapan relations in the 1990s and early 2000s, such as North Korea's nuclear weapons program, North Korea's long range missile threat, North Korean spy ships, and North Korea's kidnapping of Japanese citizens, resulted in conflict between Japanese and Koreans in Japan. By analyzing the coverage of the issues by three major Japanese newspapers Yomiuri, Mainichi, and Asahi Daily News this study finds that Japanese attacks against Koreans in Japan were affected by the information that the Japanese public received about the issues from the media. The more critical the issue was to national security, and the less satisfactory were the responses of the government to the issue, the more likely were Japanese to attack Koreans in Japan to express their grievances against North Korea and the Japanese government's reactions to the issues. The findings of this study suggest that we can fully explain ethnic conflict when we comprehensively examine the overall process of how the majority perceives the interactions between political actors involved in an incident and how they take advantage of existing ethnic tensions as a way of expressing their grievances against them, rather than attempting to explain ethnic conflict by deep-rooted attitudes about ethnic differences between the majority and the minority populations and the political or social discrimination that the minority has received in the host country.
\end{abstract}

Key Words: minority problems, Koreans in Japan, North Korea-Japan relations, media coverage, ethnic conflict

\footnotetext{
G overnments and other international organizations around the world have tried to prevent bloodshed due to violent ethnic conflicts, while assuming that democratic and developed countries were predominately peaceful without needing to result to major efforts to deal with their own minority issues. Due to globalization, which has made national borders more porous, developed countries have not been entirely free from ethnic conflicts, even though these have not

*Jeonghun Min (huni72kr@gmail.com) is a research professor in the Department of Political Science at Konkuk University. His research interests include presidential campaigns, political attitudes and electoral behavior of minority populations, and political communication and the media. He has published research in such journals as Social Science Journal, Asian Survey, International Political Science Review, Midsouth Political Science Review, and Oklahoma Politics.
}

The Korean J ournal of International Studies Vol.13-3 (December 2015), 535-553. http://dx.doi.org/10.14731/kjis.2015.12.13.3.535 
necessarily resulted in the kinds of violent conflicts seen in developing countries. ${ }^{1}$ Minorities in developed countries also often have tried to keep their own ethnic identity and culture while remaining sensitive to events in their home countries. Meanwhile, majority populations sometimes have questioned whether minorities are more loyal to their homeland due to their efforts to maintain their own identity and culture. Ethnic conflict does occur in developed countries, especially when relations between the host country and the minority's home country become tense, as suggested in Table 1. This paper focuses on ethnic conflicts between Japanese and Koreans in Japan triggered by issues generating conflict in North Korea-Japan relations in the 1990s and early 2000 .

Table 1. Major Issues in North Korea-Japan Relations in the 1990s and Early 2000s

\begin{tabular}{|c|c|c|}
\hline Year & Issue & $\begin{array}{l}\text { Incidents of Conflict Between Ethnic Japanese and } \\
\text { Koreans in Japan }\end{array}$ \\
\hline 1994 & $\begin{array}{l}\text { North Korea's nuclear weapons } \\
\text { program }\end{array}$ & Yes (155 incidents of Japanese attacks / Korean protests) \\
\hline 1997 & Kidnappings & No \\
\hline 1998 & $\begin{array}{c}\text { North Korean missile launch over } \\
\text { Japan }\end{array}$ & Yes (36 incidents of Japanese attacks / Korean protests) \\
\hline 1999 & Spy ship incident & No \\
\hline 1999 & North Korea's missile threat & No \\
\hline 2001 & Spy ship incident & No \\
\hline 2002 & Kidnappings & Yes (13 incidents of Japanese attacks / Korean protests) \\
\hline
\end{tabular}

Source: Chronology for Koreans in Japan (Minorities at Risk Project 2005).

Ethnic conflicts between ethnic Japanese and Koreans in Japan reflect that Japan, which is often cited as the quintessential example of a homogeneous society since nearly 100 percent of the population is ethnic Japanese, has also experienced problems addressing minority population issues. Table 1 above also presents an interesting relationship between issues and ethnic conflicts in Japan. Unlike North

\footnotetext{
${ }^{1}$ According to Gurr (1993), minorities in western democracies and Japan usually express their grievances in protest, rarely in rebellion, and the most common response by governments in the late twentieth century is to accommodate their interests rather than forcibly subordinate or incorporate them.

${ }^{2}$ However, at the Kim-Koizumi summit in 2002, Kim admitted that North Korea's security service abducted 13 Japanese from Japan and Europe between 1977 and 1982. Unlike in 1997, the kidnapping issue in 2002 incited ethnic conflict between Japanese and Koreans in Japan. Korean schoolgirls wearing traditional Korean dress became targets of stone-throwing, anti-Korean xenophobes (Manyin 2003).
} 
Korea's nuclear weapons program in 1994 and its testing of long-range missiles over Japan in 1998, North Korea's kidnapping of Japanese citizens in 1997 and the spy ship incidents in 1999 and 2002 did not result in ethnic conflicts between Japanese and Koreans in Japan. ${ }^{2}$ Why did some incidents result in ethnic conflict while others did not? Why did certain issues aggravate existing ethnic tensions between Japanese citizens and Koreans in Japan and eventually lead to conflict?

Previous research on minorities in Japan generally has focused on political and economic discrimination against Koreans in Japan or historical and cultural differences between Japanese and Koreans in Japan (Hicks 2004; Lee and DeVos 1981; Min 1992; Mitchell 1996; Refsing 2003; Yasunori 2000). Most of the studies largely focused on historical atrocities committed during colonial rule and political discrimination as the main causes of ethnic conflicts between Japanese and Koreans in Japan. Although existing ethnic tensions provided the fundamental pre-conditions for ethnic conflict, they cannot explain why some of the issues exacerbating tensions in North Korea-Japan relations in the 1990s and early 2000 s resulted in violent ethnic conflict while others did not. In addition, it is not clear how existing ethnic tensions can be linked to ethnic conflicts when aggravated by international issues.

This study attempts to explain how issues exacerbating tensions in North Korea-Japan relations in the 1990s and early 2000 s agitated existing ethnic tensions between Japanese and Koreans in Japan and eventually resulted in outbursts of violence by examining the impact of media coverage on those issues. By analyzing the coverage of three major Japanese newspapers, Yomiuri, Mainichi, and Asahi Daily News of the major issues causing tensions in North Korea-Japan relations in the 1990 s and early 2000s, this paper argues that media coverage of the issues played a significant role in explaining how those issues were connected to conflict between ethnic Japanese and Koreans in Japan. Specifically, Japanese attacks against Koreans in Japan were influenced by the information that the Japanese public received about the issues from the media: the more critical the issue was and the less satisfactory the reactions of their government to the issue were, the more likely were Japanese citizens to attack Koreans, whom they perceived to be representatives of North Korea, to express their grievances against North Korea and the Japanese government's reaction to the issue.

\footnotetext{
${ }^{2}$ However, at the Kim-Koizumi summit in 2002, Kim admitted that North Korea's security service abducted 13 Japanese from Japan and Europe between 1977 and 1982. Unlike in 1997, the kidnapping issue in 2002 incited ethnic conflict between Japanese and Koreans in Japan. Korean schoolgirls wearing traditional Korean dress became targets of stone-throwing, anti-Korean xenophobes (Manyin 2003).
} 


\title{
HISTORICAL BACKGROUNDS OF KOREANS IN JAPAN
}

\begin{abstract}
About 600,000 to 700,000 Koreans live in Japan today, and this number does not include Koreans who have obtained Japanese citizenship. The total number of people of Korean origin consists of at least one percent of Japan's population, which makes Koreans the largest non-'Japanese' ethnic group (Yasunori 2000). However, all members of the Korean community in Japan have encountered racial discrimination. Japan's government policy toward minorities is evident as it passed laws reinforcing the idea that Koreans are aliens and made the citizenship process difficult for Koreans. In addition, many Japanese employers demand a copy of a job applicant's family registration papers, and this requirement creates disadvantages to Korean applicants in the employment process. Although recent legislation has opened up the possibility for people of Korean descent to be hired as teachers and other kinds of civil servants, many still experience rejection on the basis of their ethnicity (Hicks 2004).

Citizenship and cultural identity have been the major issues of contention between Koreans in Japan and the Japanese government. Although Koreans are no longer required to adopt Japanese-style names according to Japan's naturalization laws, informal pressure strongly encourages them to do so (Lee and DeVos 1981). This informal pressure results from the fact that, in the Japanese tradition, citizenship and ethnicity are not separated. Accordingly, Koreans have to undergo full assimilation before they can be accepted as citizens of Japan. The term "Korean-Japanese" does not exist in Japanese society to keep the myth of racial homogeneity alive. This is hard for many Koreans to accept since they perceive that retaining their cultural identity is a fundamental right (Hicks 2004). As a consequence, there have been ethnic tensions between Japanese and Koreans in Japan by the confrontation between Japan's preservation of the myth of a homogeneous society and Koreans' maintenance of their own cultural identity.
\end{abstract}

\section{IDENTITIES OF ETHNIC JAPANESE AND KOREANS IN JAPAN}

The national and ethnic identity of the Japanese people, often cited as an exemplar of a homogeneous society in the world, originated during the era of imperial and wartime Japan (Doak 2001). As a justification for "liberating" other Asian nations, Imperial Japan emphasized the extreme unification of ethnicity and racial superiority (Fujiwara 1956; Doak 2001). Although the defeat in World War II made Japan abandon the concepts of extreme statism and racial superiority, the dismantlement of the dream for a greater East Asian empire left behind the 
myth of Japan as an ethnically "homogeneous nation" (Doak 2001). Although the "ultra-right wing" and "rightists" were gradually deprived of their influential political power (Fujiwara 1956), the conservative, ethnic group-centered identity remained (Beer 1981). Indeed, as the Yasukuni Shrine disputes in Japan show, rightists groups, activists, and intellectuals have pressed the Japanese government to support more conservative and patriotic policies (Shibuichi 2005).

Concerning Korean ethnicity, two organizations of Koreans, Mindan and Chongryon, have confronted each other over which is the legitimate representative of Koreans in Japan. ${ }^{3}$ While Mindan has focused on the problems of discrimination Koreans face in Japanese society, Chongryon members have played a role as North Korea's ideological delegates to deliver political favors back to North Korea from Japan (Lee and DeVos 1981). Chongryon's pro-North Korea attitude has faced huge confrontation from Koreans in Japan, as well as from ethnic Japanese. Furthermore, the ethnicity of Koreans in Japan has faced an identity crisis because the majority of third- and fourth-generation Koreans have tended to think that they were not Koreans, while older generations continued maintain and preserve their Korean heritage. The wide range of the depth of ethnic identification of Koreans in Japan makes it hard to describe a coherent hereditary identity. However, Chongryon and Choson Sinbo, a newspaper dealing with North Korea and Koreans in Japan, have been strong supporters of North Korea, and their activities have influenced ethnic Japanese to perceive that the identity of Koreans in Japan was almost the same as that of native Koreans.

The efforts of Koreans in Japan to keep their own ethnicity and culture have made ethnic Japanese, who have emphasized the homogeneity of Japanese society and its racial superiority, uncomfortable because ethnic Japanese were likely to perceive those efforts as a hurdle to maintaining the myth of racial homogeneity. In addition, as Koreans in Japan continued to maintain cultural links to their homeland, ethnic Japanese have seemed to be unable to disassociate them from native Koreans. Ethnic Japanese assume that such links also extend into the political realm. They perceive that Koreans in Japan are likely to be more loyal to their homeland and, hence, act as delegates for the political perspectives of the two Koreas. As a result, when contentious issues in North Korea-Japan relations have flared up, this has caused anti-Korean feelings to increase among ethnic Japanese, and Koreans in Japan likely were to be blamed for what North Korea has done to Japan (Hicks 2004).

${ }^{3}$ Mindan is a Korean organization that supports South Korea, and Chongnyon follows the ideological line of the North Korean government (Min 1992). 


\section{ISSUES IN NORTH KOREA-JAPAN RELATIONS IN THE 1990 S AND EARLY 2000S}

Japan pursued limited engagement with North Korea until the end of the Cold War due to a Cold War foreign policy that was highly influenced by the United States. Japan tried to keep equidistance between the two Koreas whenever possible. However, at the end of the Cold War, South Korea's favorable foreign policy towards two strong supporters, China and Russia, consequently forced North Korea to make overtures to Japan to be a new balancer to South Korea's foreign policies. Japan also found an opportunity to gain leverage on the Korean peninsula by discarding hostile policies towards North Korea (Fouse 2006). In January 1991, Japan and North Korea started normalization talks, which continued into 1992, but the discussions finally broke down because of North Korea's protest over the International Atomic Energy Association's inspections of North Korean nuclear facilities and Japan's request for information on a missing Japanese woman. Thereafter, several critical issues caused North Korea to be a major security concern for Japan.

Four major issues influenced North Korea-Japan relations in the 1990 s and early 200os: North Korea's nuclear weapons program, North Korea's long-range missile threat, North Korean spy ships, and North Korea's kidnapping of Japanese citizens. The mixture of these four major incidents made North KoreaJapan relations more complicated, and prompted Japan to pursue a more aggressive diplomacy in the post-Cold War era.

\section{NORTH KOREA'S NUCLEAR WEAPON PROGRAM}

The North Korean nuclear crisis in 1994 was a shock to Japan, which experienced nuclear attacks for the first time in world history during World War II. Japan consistently urged North Korea to abandon its nuclear program, but it did not have much leverage on the nuclear issue due to North Korea's attitude, which regarded the United States as the only viable partner in nuclear negotiation in 1994. Japan, as well as South Korea, just followed the results of those bilateral negotiations between North Korea and the United States and promised to pay $\$ 1$ billion of the estimated $\$ 4.7$ billion cost for the light-water nuclear reactors to be built in North Korea in exchange for North Korea's abandoning its nuclear reactor program, which produced weapons-grade plutonium. The nuclear issue disturbed normalization talks between North Korea and Japan, and thereafter Japan took a more aggressive diplomatic stance towards other issues involving North KoreaJapan relations, such as North Korea's long-range missile threat and North Korea's kidnapping of Japanese citizens. 


\section{NORTH KOREA'S LONG-RANGE MISSLE THREAT}

North Korea's test firing of a long-range missile, the Taepodong-1, in 1998 also raised another security concern for Japan since the missile's trajectory took it over Japan's airspace and into the Pacific Ocean. This missile test became another pressing security concern for Japan, which already feared North Korea's nuclear program. Japan, which has been limited to only self-defense military capabilities by its pacifist constitution, felt a serious security threat from North Korea. As a result, Japan became more resolute toward North Korea, announcing that it would freeze all food aid, withhold its financial contribution to the Korea Peninsula Energy Development Organization (KEDO), and withdraw its suggestion of normalization talks.

\section{NORTH KOREAN SPY SHIPS}

This issue started to attract attention with two incidents in 1999 and 2001. In March 1999, two suspicious boats disguised as Japanese fishing boats ran away just after the Japanese Coast Guard attempted to inspect the vessels. Despite a high-speed chase and the firing of warning shots by Japan's navy vessels and sea patrol, the two suspicious ships fled into international waters. This incident immediately triggered disputes in Japan about the country's defense capabilities and the limits its pacifist constitution placed on the use of force unless used clearly in self-defense. In 2001, Japanese Coast Guard patrol boats fired 20mm machine guns directly into another suspicious ship, which exploded and sank. The sinking was the first time since World War II that any arm of the Japanese Self-Defense Force (SDF) used force and inflicted casualties. These incidents also triggered anti-Korean sentiment among ethnic Japanese.

\section{NORTH KOREA'S KIDNAPPING OF JAPANESE CITIZENS}

The Japanese government, as well as most Japanese people, regarded the kidnapping issue as one of the most important in bilateral relations with North Korea in the 1990 s and the early 2000s. In 1997, North Korea denied its involvement in the alleged kidnappings, but the North Korean government promised to investigate the missing Japanese citizens who were allegedly abducted by North Korea. The major issue in 1997 related to the kidnappings concerned Japanese women who were later married to North Koreans. North Korea negotiated the number of visiting wives in exchange for Japanese food aid, which many viewed as a sort of hostage negotiation. However, in September 2002, Kim Jong-Il admitted that North Korea's security agency had abducted 13 Japanese citizens from Japan and Europe from the 1970s to the 1980s, and that eight were dead and five were still alive in North Korea, plunging Japan into traumatic shock. Furthermore, the 
uncertain explanations for the deaths of the eight abductees caused a huge backlash by Japan, despite Kim Jong-Il's official apology. The abduction issue was the primary complication in need of resolution for normalization talks continue.

\section{ISSUES, MEDIA COVERAGE, AND ETHNIC CONFLICT}

All four issues above exacerbated tensions in North Korea-Japan relations in the 1990 and early 2000s. North Korea's nuclear program in 1994 and its long-range missiles over Japan in 1998 resulted in ethnic conflicts between Japanese and Koreans in Japan; however, North Korea's kidnapping of Japanese citizens in 1997 and the spy ship incidents in 1999 and 2002 did not.

That Japan reacted to the issues differently suggests that the Japanese responses to the issues could have been influenced by the public's distinctive perceptions of each of the issues. Taking into account that North Korea and the Japanese government were the main political actors involved in the issues, how ethnic Japanese perceived the security threat from North Korea and evaluated the reactions of the Japanese government to the issues could have affected whether the issues exacerbated anti-Korean sentiments or if the public attacked Koreans in Japan to express grievances against North Korea and the Japanese government's handling of each issue.

How did the Japanese public receive the information about the issues involving North Korea-Japan relations and assess the reactions of the government to the issues and update public perceptions towards North Korea? The answer can be deduced from examining the impact of media coverage of the issues. Previous studies have shown that there was a connection between mass media exposure and knowledge of political events (Feldman and Kawakami 1991; Garramone and Akin 1986; Jacobs and Shapiro 1996; Kotze 1986; McLeod and McDonald 1985; Robinson 2000). Those studies found that a high volume of coverage of an issue increased its salience in the public mind and that media messages affected or primed the standards or criteria that individuals used in making evaluations. Feldman and Kawakami (1991) found that attention paid to newspaper political coverage was the best predictor of political knowledge, behavior, and interest among the public in Japan. Moreover, when there is a major political event or a political crisis, Japanese citizens turn to the national dailies, such as Yomiuri, Mainichi, and Asahi Daily News, which are well-known for their in-depth coverage and high reliability, and use them as a primary source of political information.

I posit that when the issues aggravating tensions in North Korea-Japan relations occurred in the 1990 s and early 2000s, the Japanese public turned to mass 
media, especially major national newspapers, to collect information about the issues and evaluate the reactions of the government to the issues and update public perceptions towards North Korea. The media were likely to allocate significant amounts of space for North Korea-Japan relations because the issues were vital to national security and, hence, were seen as attractive to draw the public's attention. For example, North Korea's missile program has been high on Japan's security agenda since North Korea's Taepodong-1 launch over Japan in August 1998. Japanese security officials were most concerned about North Korea's cache of up to 100 medium-range Nodong missiles that were capable of reaching anywhere in Japan (Manyin 2003). In addition, compared to the coverage of domestic issues involving political rights, education, and the social status of Koreans in Japan, 4 the media could be less cautious when going negative on North Korearelated issues in that they could pass the responsibility to North Korea or blame it for causing such political tensions. 5

The amount of media coverage on the issues exacerbating tensions in North Korea-Japan relations could affect how the Japanese people would update their perceptions of North Korea. When the issues, such as North Korea's nuclear weapons program in 1994 and North Korea's missile test over Japan in 1998, received media coverage, the Japanese public began to pay much closer attention to the issues and North Korea-Japan relations. As the media continued to cover the issues, Japanese citizens paid more attention to the issues and updated their perceptions of North Korea accordingly. Many, especially those identifying as "ultra-right wing" or "rightists," who strongly supported conservative and patriotic policies, were likely to have grievances against North Korea because they perceived the communist country to be posing a grave security threat. ${ }^{6}$ As the amount of coverage of the issues increased, therefore, their grievances against North Korea were likely to get stronger and their anti-Korean feelings were like-

\footnotetext{
${ }^{4}$ Domestic issues warranted greater media consideration about the ramifications of negative reporting. Japan signed a number of human rights treaties in the late 1970s and early 1980s directly affecting domestic developments on human and minority rights, such as court decisions and local government policies (Strausz 2006). However, the United Nations Human Rights Committee warned that it would consider investigating Japan's treatment of its Korean residents in August 1990. In addition, in October 1998, the United Nations Human Rights Panel announced its conclusion that Japan had made no significant progress on human rights in the previous five years. One of the problems cited was persistent discrimination in the education of Korean children (Minorities at Risk Project 2005).

5 Budner and Krauss (1995) showed that Japanese news reports were more likely to blame the United States than Japan in the coverage of U.S.-Japan frictions than were American media reports.

${ }^{6}$ According to one survey, more than 50 percent of Japanese considered North Korea as the biggest military threat to their country. See "U.S. still most trustworthy, but slipping," The Daily Yomiuri. May 3, 1994.
} 
ly to increase as well. Given this situation, based on Japanese perceptions of the ethnic-based difference in loyalties that Koreans in Japan were perceived to have, ethnic Japanese were more likely to attack Koreans in Japan, especially female Korean students wearing traditional Korean clothing to school, to express their grievances against North Korea. In response to these Japanese attacks, Koreans in Japan protested against the Japanese government to better secure their safety.

H1: The greater the media coverage of issues of conflict in North KoreaJapan relations, the more likely are ethnic Japanese to attack ethnic Koreans in Japan.

Whether ethnic Japanese would attack Koreans in Japan could also be affected by the tone of the media coverage on the issues aggravating tensions in North Korea-Japan relations. As the issues continued to receive media coverage, the Japanese public was likely to pay more attention to how the government reacted to those issues (Feldman and Kawakami 1991).

The responses of the Japanese government to the issues can be divided into two categories: the reactions of the Japanese government to North Korea and the measures that the Japanese government took to cope with the issues. For the reactions to the Japanese government's response to North Korea, those who perceived North Korea to impose a grave security threat were likely to expect that their government would show a strong response to North Korea, such as forcefully criticizing or condemning North Korea for its reckless and unforgivable misbehavior. If the public could see more news articles showing that the government strongly criticized or condemned the security threat of North Korea then the more likely was that public to perceive that the government was taking appropriate measures to deal with the communist country. As a consequence of that coverage, ethnic Japanese would be less likely to attack Koreans in Japan. In contrast, if ethnic Japanese encountered a smaller number of news articles about their government's strong reaction to North Korea, they would be more likely to perceive that their government was not responding appropriately to the security threat from North Korea. In this situation, ethnic Japanese were more likely to act on their perception that Koreans in Japan were delegates for their homeland and then attack the minority to express their grievances. When attacked by ethnic Japanese, Koreans in Japan would protest against the Japanese government to secure their safety.

H2: If media coverage was more negative in tone towards North Korea about an issue aggravating tensions in North Korea-Japan relations, ethnic Japanese were less likely to attack Koreans in Japan. 
The measures that the Japanese government took to cope with the issues aggravating tensions in North Korea-Japan relations could also affect whether ethnic Japanese would attack Koreans in Japan. Japanese who viewed North Korea as a grave security threat were likely to expect their government to take immediate, decisive steps to address the issues. When news articles were filled with a more positive tone towards the Japanese government's response of immediate and effective measures to address the issues, ethnic Japanese were more likely to perceive that their government was taking proper steps in line with their expectations. As a consequence, they would be less likely to attack Koreans in Japan. However, if they read more news articles criticizing their government's indecisiveness or ineffectiveness in taking steps to cope with the issues, they were more likely to think that their government did not follow along with their expectations and, hence, their grievances would increase. In this situation, they were more likely to attack Koreans in Japan. In response to the attacks, Koreans in Japan would protest against the Japanese government to better ensure their safety.

H3: If media coverage showed a more negative tone towards the Japanese government's reactions to an issue aggravating tensions in North Korea-Japan relations, ethnic Japanese were more likely to attack Koreans in Japan.

Figure 1 presents the path model showing how an issue aggravating tensions in North Korea-Japan relations could result in conflict between ethnic Japanese and Koreans in Japan.

Figure 1. Path Model of Ethnic Conflict between Japanese and Koreans in Japan

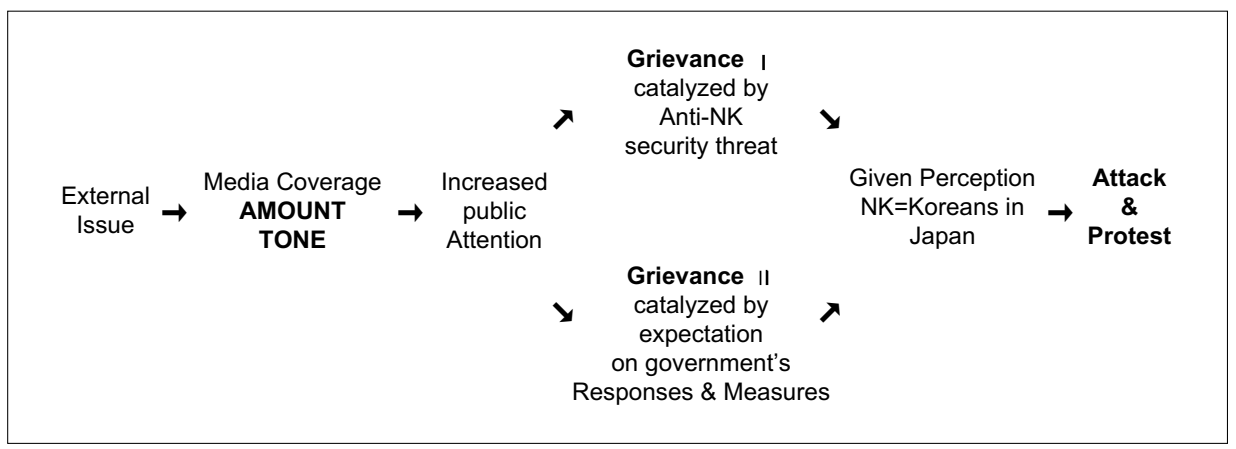




\section{RESEARCH DESIGN}

To empirically test the hypotheses of this study, I analyzed the coverage of three major Japanese newspapers, Yomiuri, Mainichi, and Asahi Daily News, on the main issues exacerbating tensions in North Korea-Japan relations in the 1990 and early 2000s. As shown in Table 1, the issues include North Korea's nuclear weapons program in 1994, North Korea's kidnapping of Japanese citizens in 1997 and 2002, North Korea's launching of a long-range missile over Japan in 1998 and North Korea's missile threat in 1999, and North Korean spy ships in 1999 and 2001.7 Content analysis of the coverage of each individual issue was conducted for six months beginning from the date when the newspapers started to cover the issue.

The dependent variable is "Japanese Attacks," which is defined as Japanese attacks against Koreans in Japan triggered by the selected issues of this study. To differentiate Japanese attacks related to ethnic conflict due to the issues from general criminal attacks against Koreans in Japan, two criteria were adopted: the attack should be clearly related to the issue exacerbating tensions in North KoreaJapan relations and the target should be recognizable in ethnic identity. ${ }^{8}$ If an attack did not meet the criteria, it was regarded as a crime not an ethnic attack

\footnotetext{
${ }^{7}$ It can be argued that other types of media, such as television and radio, might have more significant influence on Japanese political behavior than newspapers since the former are non-selective and have wider coverage in terms of accessibility. As I mentioned earlier, however, Japanese peopel are more likely to turn to newspapers, especially national dailies, because of Japan's cultural reliance on written materials when there is a major political event or a political crisis in order to get more detailed and reliable information about the issues (Feldman and Kawakami 1991). In addition, although specific content may differ from day to day, it was expected that, over time, the trend in coverage of the issues in the major newspapers was similar to that found in other media sources. Analyzing the three major newspapers' coverage of the selected issues of this study, therefore, is relevant to examining the impact of media coverage on ethnic conflict between Japanese and Koreans in Japan. The three national dailies had a combined total circulation of 28.7 million in 1991.

${ }^{8}$ The following article is an example of Japanese attacks against Koreans in Japan based on an issue exacerbating tensions in North Korea-Japan relations. "The officials said especially harassments against female students, who wear easily identifiable ethnic Korean dress, have been on the rise. They attributed the rise to the growing anti-North Korea sentiment in Japan fanned up by reports of suspected nuclear development by Pyongyang. The Tokyo Korean Junior and Senior High School in Kita$\mathrm{ku}$, Tokyo, is going to request the Metropolitan Government to take countermeasures to stop harassment. One of the latest such attacks occurred Wednesday, when a man cut a 50-centimeter slit in the dress of a 14-year-old ethnic Korean girl on a train. The man chased the female student into another carriage and slashed her skirt, police said. The attacker said something like "North Korea" and "nuclear," to the girl, who was wearing chima chogori ethnic dress, a school uniform, at the time of attack, they added. Ethnic Korean students have often become a target of harassment when disputes with North Korea heated up, such as in 1987 when a Korean Airline jetliner was bombed midair, allegedly by North Korean spies." See "Korean students were attacked," Mainichi Daily News. June 17, 1994 .
} 
and was excluded from the dataset of this study. The variable was measured as the number of Japanese attacks against Koreans in Japan that appeared in the newspapers during the time period (six months) of content analysis for each issue. Unfortunately, it was not possible to collect the data indicating the specific date when each attack occurred. Alternatively, it was possible to gather the data on the aggregate number of attacks for a certain period of time. For instance, for North Korea's nuclear weapons program in 1994, data were available to collect from a news article on July 27 that stated, "There have been 155 attacks against Koreans in Japan as of today since the issue was revealed to the public." To match the units of observation between the Japanese attacks and the media coverage on the issue, the aggregate number of attacks was disaggregated to a daily average between March 26 and July 27, 1994. This method is also applied to Japanese attacks following media coverage of the other issues.

The main independent variable used was "Media Coverage," which has two dimensions: "Amount of Coverage" and "Tone of Coverage." The former is operationalized by the amount of coverage of the issues and the latter is operationalized by the negative tone of the coverage on North Korea and the Japanese government. These are measured by analyzing the coverage of the three newspapers of the issues using computer coding and index searching made available by the LexisNexis search program. "Amount of Coverage" was measured by counting the number of words in each article covering the issue during six months since the issue was revealed to the public.

For the variable "Tone of Coverage," the number of words in each article delivering a negative tone towards North Korea and the Japanese government, respectively, were examined. To minimize subjectivity in measuring the variable, this study uses the following criteria adapted from research on Japanese newspapers by Budner and Krauss (1995). A paragraph was considered to be negative if it criticized or condemned North Korea for the issue, including criticizing North Korea's motivations for the incident. Likewise, when a paragraph criticized the Japanese government for not taking immediate, decisive measures to address the issue, it was regarded as being negative. This research does not count key words and phrase in terms of negative tone because the overall context of a paragraph is more important than a single or several key words in a reader's interpretation of the paragraph (Graber 1993).

The variable "Culture Difference" is included in the model considering that ethnic and cultural differences between Japanese and Koreans in Japan could be the deep-rooted cause of ethnic conflict. 9 I use data from the Minorities at Risk

${ }^{9}$ Gurr (1993) categorizes Koreans in Japan as “ethno classes.” The main issues of ethnic conflict 
Project to measure the cultural difference between ethnic Japanese and Koreans in Japan. ${ }^{10}$ The variable is operationalized by the "Different Social Customs" index in the data, which is a three-category scale of cultural differentials. ${ }^{11}$

Finally, this research attempts to determine "Level of Hostility" in the model. This variable indicates the hostility levels reached across the issues exacerbating tensions in North Korea-Japan relations where the two states in a dyad were on opposite sides. The variable was included in the model to measure the impact of the seriousness of the issues on ethnic conflict taking into account whether to take military action in response to an incident reflected how critical the incident was to national security. This study uses Correlates of War2 Project data to measure the Level of Hostility. ${ }^{12}$ The variable is operationalized by "Hostility Level of Japan” and "Hostility Level of North Korea." The former shows Japan's highest hostility level against North Korea regarding the issue, while the latter indicates North Korea's highest hostility level against Japan caused by the issue. Each was measured by using a five-category scale. ${ }^{13}$

The Ordinary Least Squares (OLS) Regression with robust standard errors, which can be used to treat the problem of heteroscedasticity, was used to empirically test the hypotheses of this study. ${ }^{14}$

for this type of minority group are usually demands for a reduction in political and economic inequality, and for cultural rights. In addition, Carment (1994) points out that previous studies considered a combination of economic, political, symbolic, and psychological factors to explain what caused ethnic conflict and how ethnic conflict could influence international relations. However, the two variables of 'political inequality' and 'economic inequality' were not relevant for this study because the ethnic conflicts between ethnic Japanese and Koreans in Japan triggered by the issues aggravating tensions in North Korea-Japan relations have nothing to do with Koreans' demand for improvement in their political or economic rights. Thus, the two variables were not included in the model.

${ }^{10}$ Minorities at Risk Project. 2005. College Park, MD: Center for International Development and Conflict Management. Accessed at http://www.cidcm.umd.edu/mar/ (November 30, 2015).

${ }^{11}$ Each numerical value from $\mathrm{o}$ to 2 stands for the following: $\mathrm{O}=$ No differential, $1=$ Some indeterminate differential, and 2 = Significant differential.

12 “The Dyadic Militarized Interstate Dispute Data, 2007. Correlates of War2 Project. Pennsylvania State University. Accessed at http://correlatesofwar.org (November 30, 2015).

131 = No militarized action, 2 = Threat to use force, $3=$ Display use of force, $4=$ Use of force, and $5=$ War.

14 The result of White's test shows that heteroscedasticity is present in the data set of this study, thus I employed the regression model to treat the problem of heteroscedasticity. 


\section{RESULTS}

Table 2. OLS Regression with Robust Standard Errors for Japanese Attacks against Koreans in Japan in the 1990s and Early 2000s

\begin{tabular}{|c|c|c|}
\hline & Coefficient & P-Value \\
\hline $\begin{array}{l}\text { Media Coverage } \\
\text { Amount of Coverage }\end{array}$ & $\begin{array}{l}.0002^{* * *} \\
(.00006)\end{array}$ & 0.004 \\
\hline Negative Tone on North Korea & $\begin{array}{c}-.0004 \\
(.00026)\end{array}$ & 0.158 \\
\hline $\begin{array}{l}\text { Negative Tone on the Japanese } \\
\text { Government }\end{array}$ & $\begin{array}{l}.0005^{* *} \\
(.00023)\end{array}$ & 0.033 \\
\hline Cultural Difference & $\begin{array}{l}.1181^{* * *} \\
(.01104)\end{array}$ & 0.000 \\
\hline $\begin{array}{l}\text { Level of Hostility } \\
\text { Hostility Level of Japan }\end{array}$ & $\begin{array}{r}-.5827^{* * *} \\
(.03536)\end{array}$ & 0.000 \\
\hline Hostility Level of North Korea & $\begin{array}{l}.1290 * * * \\
(.00797)\end{array}$ & 0.000 \\
\hline Constant & $\begin{array}{c}1.4817^{* * *} \\
(.09169)\end{array}$ & 0.000 \\
\hline $\mathrm{N}$ & 1260 & \\
\hline Prob> F & 0.0000 & \\
\hline R-squared & 0.5305 & \\
\hline
\end{tabular}

*** $=$ statistically significant at the .01 level

** $=$ statistically significant at the .05 level

Note: Standard errors are listed in parentheses.

The results of the analysis show that media coverage of the issues exacerbating tensions in North Korea-Japan relations in the 1990s and early 2000s influenced Japanese attacks against Koreans in Japan. The finding for the variable "Amount of Coverage" shows that the more the media covered the issues, the more likely were attacks against Koreans in Japan by ethnic Japanese. The coefficient of the variable indicated that if each article dealing with North Korea's nuclear program in 1994 consisted of 500 words, for example, Japanese were likely to take part in additional attacks against Koreans in Japan when they received ten articles dealing with the issue.

The finding for the variable "Negative Tone on the Japanese Government" shows that the more Japanese newspapers devoted space to coverage with a negative tone in relation to the Japanese government's reaction to the issues, the more ethnic Japanese were willing to attack Koreans in Japan. The coefficient of the variable showed that if each article covering North Korea's long-range missile launch over Japan in 1998 was made up of 400 words, for instance, ethnic 
Japanese were willing to take part in an additional attack against Koreans in Japan when they read five articles criticizing their government's indecisiveness or ineffectiveness in taking steps to address the issue.

The result for the variable "Negative Tone on North Korea" was not statistically significant, but the negative direction of the coefficient of the variable implied the possibility that Japanese grievances towards their government's responses to North Korea might be related to Japanese attacks against Koreans in Japan.

The results of the analysis also show that cultural difference between ethnic Japanese and Koreans in Japan had an influence on ethnic conflict: the more ethnic Japanese perceived Koreans to be culturally different from them, the more likely were Japanese to attack Koreans. In addition, ethnic Japanese were more likely to attack Koreans in Japan when the Japanese government's reactions to North Korea were more dovish or if the North Korean security threat was higher.

The overall findings showed that media coverage of the issues causing serious tensions in North Korea-Japan relations in the 1990s and early 2000 s played a significant role in explaining how the issues resulted in conflict between Japanese and Koreans in Japan. When relations between North Korea and Japan became increasingly contentious, ethnic Japanese evaluated the responses of their government to the issues and updated their perceptions towards North Korea according to the media coverage of the issues. If they perceived that North Korea was imposing a serious security threat to Japan, and that their government's response to address the threat was not meeting their expectations, their antiKorean sentiments and their grievances against North Korea and their government increased. Based on their perception that Koreans in Japan were culturally different and that Koreans were delegates for their homeland, ethnic Japanese attacked Koreans in Japan - especially female Korean students wearing traditional Korean dress to school - to express their grievances. The Korean minority then protested against the Japanese government to better ensure their safety.

\section{CONCLUSION}

By analyzing the coverage of three Japanese newspapers, Yomiuri, Mainichi, and Asahi Daily News, of the issues exacerbating tensions in North Korea-Japan relations in the 1990s and early 2000s, this study showed that the scope and tone of that media coverage correlated with Japanese attacks against Koreans in Japan. Ethnic Japanese received information about the issues from the media, evaluated the reactions of their government to the issues, and updated their perceptions toward North Korea based on that coverage. If ethnic Japanese perceived that 
North Korea was imposing a serious security threat, and that their government did not take appropriate steps to cope with that threat, their anti-Korean sentiments and their grievances against North Korea and their government increased. Media coverage influenced the perception that Koreans in Japan were delegates for their homeland and attacked Koreans in Japan - especially female Korean students wearing traditional clothing to school - to express their grievances.

The primary contribution of this study lies in the revelation of how an incident exacerbating tensions in the relations between a host country and the homeland of a minority population can exacerbate existing ethnic tensions between the majority and the minority and eventually result in ethnic conflict. The connection between incidents and ethnic conflict is mainly dependent upon the perceptions of the majority of the political actors involved in the incidents, and the media play a significant role in forming those perceptions. It suggests that we can fully explain ethnic conflict when we comprehensively examine the overall process of how the majority perceives the interactions between political actors involved in an incident and how they take advantage of existing ethnic tensions as a way of expressing their grievances against them, rather than attempting to explain ethnic conflict by deep-rooted attitudes about ethnic differences between the majority and the minority populations and the political or social discrimination that the minority has received in the host country. This insight should also shed light on our attempts to understand ethnic conflicts in other developed countries.

Future research may include the influence of other types of media, such as television and radio, to develop a more comprehensive model of the impact of media coverage on conflict between Japanese and Koreans in Japan. This study only examined how the coverage of three major Japanese newspapers of several major security issues involving North Korea and Japan shaped ethnic conflict. Future research also may include some qualitative studies, such as interviews with the people who were directly involved in such ethnic conflicts, and this could contribute to making the main arguments of this research more persuasive.

\section{REFERENCES}

Beer, Lawrence W. 1981. "Group Rights and Individual Rights in Japan.” Asian Survey 21(4), 437-453.

Budner, Stanley and Ellis S. Krauss. 1995. "Newspaper Coverage of U.S.-Japan Frictions: Balance and Objectivity." Asian Survey 35(4), 336-356.

Carment, David. 1994. "The Ethnic Dimension in World Politics: Theory, Policy and Early Warning." Third World Quarterly 15(4), 551-582. 
Doak, Kevin M. 2001. "Building National Identity through Ethnicity: Ethnology in Wartime Japan and After." Journal of Japanese Studies 27(1), 1-39.

Fause, David. 2006. "Japan's Post-Cold War North Korea Policy: Hedging toward Autonomy?” In Yoichiro Sato and Satu Limaye. eds. Japan in a Dynamic Asia, Lanham, MD: Lexington books, 135-156.

Feldman, Ofer and Kazuhisa Kawakami. 1991. "Media Use as Predictors of Political Behavior: The Case of Japan." Political Psychology 12, 65-80.

Fujiwara, Hirotatsu. 1956. "Nationalism and the Ultraright Wing." Annals of the American Academy of Political and Social Science 308, 76-84.

Garramone, Gina M. and Atkin, K. Charles. Atkin. 1986. "Mass Communication and Political Socialization: Specifying the Effects." Public Opinion Quarterly 50, 76-86.

Govers, Cora, and Hans Vermeulen, eds. 1997. The Politics of Ethnic Consciousness. New York: St. Martin's Press.

Graber, Doris. 1993. "Political Communication: Scope, Progress, Promise." In Ada W. Finifter. ed. Political Science: The State of the Discipline II, Washington, D.C.: American Political Science Association, 305-332.

Gurr, Ted. R. 1993. Minorities at Risk: A Global View of Ethnopolitical Conflicts. Washington, D.C.: United States Institute of Peace Press.

Hicks, George. 2004. Japan's Hidden Apartheid: The Korean Minority and the Japanese. Aldershot, UK: Ashgate Publishing Ltd.

Jacobs, Lawrence and Robert Y. Shapiro. 1996. "Toward the Integrated Study of Political Communications, Public Opinion, and the Policy-Making Process." PS: Political Science and Politics 29(1), 10-13.

Kotze, Hendrik J. 1986. "Mass Media and Political Socialization: A South African Case Study." International Political Science Review 7, 415-434.

Lake, David A., and Donald Rothchild, eds. 1998. The International Spread of Ethnic Conflict: Fear Diffusion, and Escalation. Princeton, NJ: Princeton University Press.

Lee, Changsoo and George DeVos. 1981. Koreans in Japan: Ethnic Conflict and Accommodation. Berkeley and Los Angeles: University of California Press.

Malesevic, Sinsa. 2004. The Sociology of Ethnicity. Thousand Oaks, CA: SAGE Publications.

Manyin, E. Mark. 2003. “Japan-North Korea Relations: Selected Issues.” CRS Report for Congress. Accessed at http://www.nautilus.org/DPRK BriefingBook/ Japan/CRS (November 30, 2015).

McLeod, Jack M. and McDonald, G. Daniel. 1985. "Beyond Simple Exposure: Media Orientations and Their Impact on Political Processes." Communication 
Research 12, 3-33.

Min, Pyong Gap. 1992. "A Comparison of the Korean Minorities in China and Japan." International Migration Review 26, 4-21.

Minorities at Risk Project. 2005. College Park, MD: Center for International Development and Conflict Management. Accessed at http://www.cidcm. umd.edu/mar/ (November 30, 2015).

Mitchell, Richard. 1996. The Korean Minority in Japan. Berkeley and Los Angeles: University of California Press.

Refsing, Kirsten. 2003. "In Japan, but not of Japan." In Colin Mackerras. ed. Ethnicity in Asia, New York: Routledge Curzon, 48-63.

Robinson, Piers. 200o. "The Policy-Media Interaction Model: Measuring Media Power during Humanitarian Crisis." Journal of Peace Research 37, 613633.

Shibuichi, Daiki. 2005. "The Yasukuni Shrine Dispute and the Politics of Identity In Japan: Why All the Fuss?” Asian Survey 45(2), 197-215.

Strausz, Michael. 2006. "Minorities and Protest in Japan: The Politics of the Fingerprinting Refusal Movement." Pacific Affairs 79(4), 641-656.

The Dyadic Militarized Interstate Dispute Data. 2007. Correlates of War2 Project, Pennsylvania State University. Accessed at http://correlatesofwar.org (November 30, 2015).

Yasunori, Fukuoka. 2000. Lives of Young Koreans in Japan. Melbourne: Trans Pacific Press. 